\title{
O INDIVÍDUO, A EDUCAÇÃO E A CRISE ECONÔMICA SEGUNDO KARL MARX
}

\author{
Fernando Frota Dillenburg ${ }^{1}$
}

\section{Resumo:}

Procuramos mostrar neste artigo como Marx descreve, em $O$ capital, o desenvolvimento dos indivíduos, assim como a relação destes com a educação e com a crise do capital. No início d'O capital os indivíduos encontram-se totalmente enfeitiçados pela mercadoria e pelo dinheiro. Na seção II eles já aparecem como representantes de classes sociais, o capitalista e o proletário, mas ainda totalmente submetidos ao movimento de autovalorização do valor, isto é, o movimento do capital. No entanto, os proletários vão, aos poucos, por meio da luta de classes, desvelando os enigmas que encobrem as verdadeiras relações entre as classes, até descobrir, no capítulo XXIV, a origem da propriedade privada capitalista. O proletariado torna-se, então, uma classe revolucionária mostrandose capaz de realizar a expropriação dos expropriadores. O Livro I expressa, assim, o processo da luta de classes através do qual o proletariado poderá, caso consiga percorrer este árduo percurso, sair das trevas nas quais se encontra em sua vida cotidiana e passar a se organizar enquanto uma classe que compreende e põe em prática um programa revolucionário. A vivência do proletariado na luta contra o capital é descrita por Marx como um processo educativo. Depois de realizar uma primeira totalização no Livro I, uma totalização ainda abstrata, Marx retoma no Livro II o domínio do capital sobre os indivíduos. Nos Departamentos I (produtor de meios de produção) e II (produtor de meios de subsistência), o capital se relaciona consigo mesmo, a ponto de conduzir a si próprio a crises cada vez mais profundas. No Livro III, Marx mostra que as contradições internas do próprio capital, isto é, as contradições da luta de classes, geram uma tendência à crises econômicas, que se tornam inevitáveis no capitalismo. Nesse Livro III Marx inclui mais uma terceira classe social: além da classe capitalista (que vive do lucro) e da classe trabalhadora (que vive do salário), aparece a classe dos proprietários fundiários (que vive da renda da terra). No capítulo LII, capítulo inacabado, Marx pretendia expor a luta de classes como fundamento dos três livros e de todo o modo de produção capitalista.

Palavras-chave: Karl Marx, O Capital, Crise

\begin{abstract}
:
We tried to show through this article how Marx describes in "The Capital", the individuals development, as well as their relationship with the education and the capital crisis. At the beginning of "The Capital", individuals are totally bewitched by goods and money. In the section II, they already appear as representatives of social classes, the capitalist and proletarian, but they still are totally subjected to the movement of self

\footnotetext{
1 Doutor em Filosofia pela Universidade Estadual de Campinas (UNICAMP); Pesquisador e pós-doutorando em Filosofia pela Universidade Estadual de Campinas (UNICAMP). E-mail: fernandofrota@ig.com.br
} 
increase in value of the value, namely, the Capital movement. However, proletarians will gradually through the classes struggle, unveiling mysteries that conceal the true relationships between classes, until they discover, in Chapter XXIV, the origin of the capitalist private property. Then, the proletariat becomes a revolutionary class showing themselves capable of carrying out the expropriation of expropriators. So, the book I expresses the process of class struggle through which the proletariat might, if it get to go through this arduous route, go out of the darkness in which are in their daily life and organize themselves as a class that understands and implements a revolutionary program. The proletariat experience in the struggle against the Capital is described by Marx as an educational process. After doing an initial totalization in Book I, an abstract totalization, Marx resumes in Book II about the capital domain on individuals. In Departments I (producer of the means of production) and II (Producer of means of subsistence), the capital relates to itself on the point of lead itself to deeper crisis. In Book III, Marx shows that the internal contradictions of the own Capital, that is, the classes struggle contradictions create a tendency to economic crises that become inevitable in capitalism. In this Book III Marx includes a third social class: beyond the capitalist class (who lives of the profit) and the working class (who lives of the wage), there is the class of landowners (who lives of the land income). In Chapter LII, the unfinished chapter, Marx intended to expose the struggle between the classes as the basis of three books and of all the mode of capitalist production.

Keywords: Karl Marx, The Capital, crisis.

Introdução

O tema "indivíduo e educação na crise do capitalismo" proposto como eixo da primeira edição da Revista Dialectus é extremamente atual e abre um amplo espaço para reflexão e debate sobre as alternativas possíveis para a emancipação do indivíduo.

Nesse sentido, cabe levantar alguns questionamentos iniciais: que papel teria o indivíduo na sociedade capitalista? Como poderia ser pensada uma educação libertadora dos indivíduos? Para discutir estas questões, propomos analisar a perspectiva apontada por Karl Marx, sobretudo em sua obra madura, O capital. Esta escolha teórica deve-se ao fato de Marx ter exposto em $O$ capital o processo de desenvolvimento do indivíduo, assim como um processo de educação a partir de suas próprias experiências cotidianas, além de ter analisado as contradições imanentes do sistema capitalista que o conduzem inevitavelmente à crise.

Procuraremos expor neste artigo o que consideramos ser um percurso realizado pelo indivíduo desde a Seção I do Livro I até a Seção VII, última do Livro I, e depois, de forma sintética, nos livros II e III d'O capital. Seguindo a interpretação de Benoit (1996) sobre $O$ capital, procuraremos extrair aquelas indicações sobre indivíduo e a educação nos apoiando no modo dialético de exposição da obra.

\begin{tabular}{|l|l|l|l|l|}
\hline Revista Dialectus & Ano 1 & n. 1 & Julho-Dezembro 2012 & p. 25-45 \\
\hline
\end{tabular}




\section{Seção I - "Mercadoria e Dinheiro" \\ Da ausência do indivíduo ao indivíduo abstrato}

Marx inicia $O$ capital se propondo a analisar a mercadoria como a forma elementar da riqueza nas sociedades em que domina o modo de produção capitalista. Nesse momento inicial da exposição, as mercadorias aparecem dotadas de vida própria, como sujeitos que vão sozinhos ao mercado para trocar-se por outras mercadorias. Nas relações de troca que estabelecem entre si, cada mercadoria cumpre um determinado papel. Assim, diz Marx no capítulo I:

Duas mercadorias diferentes, A e B, em nosso exemplo linho e casaco, representam aqui, evidentemente, dois papéis distintos. O linho expressa seu valor no casaco, o casaco serve de material para essa expressão de valor. A primeira mercadoria representa um papel ativo, a segunda um papel passivo. (MARX, 1983, p. 54)

Aqui no capítulo I as mercadorias são descritas como coisas que se apropriam da subjetividade dos indivíduos, seus produtores. A fantasmagoria que envolve a forma mercadoria dos produtos do trabalho chega ao ponto de fazer com que elas próprias elejam, mediante o desenvolvimento das trocas, aquela mercadoria que vai servir como equivalente geral, isto é, aquela mercadoria que cumprirá o papel de representante geral do valor de todas as outras mercadorias. Essa tarefa, a tarefa de eleger um equivalente geral, diz Marx, "é obra comum do mundo das mercadorias". E continua Marx: "uma mercadoria só ganha a expressão geral do valor porque simultaneamente todas as demais mercadorias expressam seu valor no mesmo equivalente e cada nova espécie de mercadoria que aparece tem que fazer o mesmo". (MARX, 1983, p. 67)

Segundo Marx, essa ideia absurda de que as mercadorias teriam autonomia frente aos indivíduos é o fundamento de toda a economia política burguesa. Um exemplo de quanto isto ainda persiste atualmente pode ser observado ao assistir o comentário de um economista em um dos telejornais. Nos meios de comunicação é comum ouvir a expressão "o mercado está nervoso", ou "o mercado não concorda com tal tendência", etc. Isso mostra como a linguagem da economia política está repleta de ideologia, está fundamentada na ideia de que o mercado, esse sujeito transcendental, impessoal e onipresente, tem consciência própria e domina a todos os indivíduos.

Marx mostra que o dinheiro, que nada mais é do que o resultado do monopólio exercido pelo ouro no papel de equivalente geral (MARX, 1983, p. 69), domina os

\begin{tabular}{|l|l|l|l|l|} 
Revista Dialectus & Ano 1 & n. 1 & Julho-Dezembro 2012 & p. 25-45 \\
\hline
\end{tabular}


indivíduos de maneira ainda mais profunda do que as mercadorias, por ser a sua forma mais brilhosa e ofuscante. (MARX, 1983, p. 85)

Como se vê, neste momento ainda inicial da exposição d' $O$ capital as mercadorias e o dinheiro dominam os indivíduos e parecem agir de maneira independente destes. Os indivíduos, ao contrário, tornaram-se totalmente reféns das mercadorias e do dinheiro, dedicando-se toda a sua vida para colecioná-los. As próprias relações entre os produtores de mercadorias aparecem para eles, de acordo com Marx, "como o que são, isto é, não como relações diretamente sociais entre pessoas em seus próprios trabalhos, senão como relações reificadas entre as pessoas e relações sociais entre as coisas”. (MARX, 1983, p. 71)

Quando um indivíduo, após vender sua mercadoria em troca de dinheiro compra outra mercadoria, não lhe parece que neste ato está estabelecendo uma relação social com inúmeros outros produtores de mercadorias. A mediação do dinheiro na troca das mercadorias ofusca o verdadeiro processo, que aparece para os produtores como uma relação entre coisas, isto é, entre o dinheiro e as mercadorias. De fato, diz Marx, esta relação aparece assim porque é assim, pois quem não tem dinheiro não tem condições de comprar mercadorias e não conseguirá, em consequiência, estabelecer uma relação social com outros produtores. Por esta razão, a relação de compra e venda não aparece como uma relação entre produtores, mas como uma relação entre coisas, entre a mercadoria e o dinheiro. Na sociedade capitalista, as mercadorias e do dinheiro se interpõem como intermediários indispensáveis nas relações sociais entre os homens. Em outras palavras, a dependência objetiva dos indivíduos às mercadorias e ao dinheiro, o fato dos indivíduos não conseguirem sobreviver sem estabelecer relações com as mercadorias e com o dinheiro é o que gera o feitiço exercido por estes sobre os indivíduos.

Com o desenvolvimento histórico da forma mercadoria e do dinheiro, os indivíduos foram perdendo o controle sobre o processo de produção de suas próprias vidas, passando a ser dominados por ele. Como o modo de produção capitalista foi responsável por generalizar a produção de mercadorias e a intermediação das trocas por dinheiro, o feitiço exercido por estas coisas também se generalizou. Marx decidiu tomar este feitiço como ponto de partida da exposição d'O capital porque é um fenômeno geral que afeta todos os indivíduos. Marx parte, portanto, da consciência mais ilusória, imediata e aparente que os indivíduos assumem em sua vida cotidiana. Por isso, os 
indivíduos aparecem em $O$ capital, de início, totalmente dominados e enfeitiçados pelos produtos de suas próprias mãos, as mercadorias e o dinheiro.

No capítulo II Marx realiza uma superação do feitiço causado pela mercadoria e pelo dinheiro sobre o indivíduo, ainda que se trate de uma superação provisória, indeterminada. Marx avança, assim, no processo de aumento da subjetividade do indivíduo, mas este aparecerá ainda aqui como mero refém das mercadorias, cumprindo um papel subordinado, o papel de guardião das mercadorias. Assim afirma Marx no início do capítulo II: "as mercadorias não podem por si mesmas ir ao mercado e se trocar. Devemos, portanto, voltar a vista para seus guardiões, os possuidores de mercadorias". (MARX, 1983, p. 79)

Percebe-se então que no capítulo II Marx superou a autonomia absoluta que as mercadorias e o dinheiro possuíam frente aos indivíduos no capítulo anterior. Apesar de já aparecerem com um determinado papel, os indivíduos ainda são representados aqui de maneira extremamente abstrata, aparecem como iguais possuidores de mercadorias que vão ao mercado para atender seus interesses recíprocos.

Para que essas coisas se refiram umas às outras como mercadorias, é necessário
que os seus guardiões se relacionem entre si como pessoas, cuja vontade reside
nessas coisas, de tal modo que um, somente de acordo com a vontade do outro,
portanto cada um apenas mediante um ato de vontade comum a ambos, se
aproprie da mercadoria alheia enquanto aliena a própria. (MARX, 1983, p. 79)

Estas relações idílicas nas quais todos os indivíduos saem do mercado com suas necessidades atendidas serão superadas mais à frente. Essa é a indicação feita por Marx a seguir: "veremos no curso do desenvolvimento, em geral, que os personagens econômicos encarnados pelas pessoas nada mais são que as personificações das relações econômicas, como portadores das quais elas se defrontam”. (MARX, 1983, p. 80) Marx está antecipando que no decorrer da exposição d' $O$ capital os indivíduos vão cumprir papéis diferentes, papéis mais determinados em relação a estes assumidos aqui.

Ainda no capítulo II, Marx ressalta que nas sociedades produtoras de mercadorias os indivíduos não controlam suas próprias condições de produção e acabam estabelecendo uma conduta meramente atomística, ou seja, agem como indivíduos isolados uns dos outros. Por essa mesma razão, os indivíduos tornam-se reféns de suas próprias relações de produção, (MARX, 1983, p. 85) das quais eles possuem uma imagem reificada. O processo de superação da reificação inicia na seção II.

\begin{tabular}{|l|l|l|l|l|}
\hline Revista Dialectus & Ano 1 & n. 1 & Julho-Dezembro 2012 & p. 25-45 \\
\hline
\end{tabular}




\title{
Seção II - "A Transformação do Dinheiro em Capital” \\ A modificação da fisionomia dos personagens do drama
}

Na seção II, única seção composta por um único capítulo, o capítulo IV², Marx opera uma mudança radical no papel que os indivíduos vinham desempenhando na seção I. Essa alteração ocorre durante a passagem da instância da circulação para a instância fundamental da produção, onde

\begin{abstract}
o segredo da fabricação da mais-valia há de se finalmente desvendar (...) Ao sair dessa esfera da circulação simples ou da troca de mercadorias, da qual o livre-cambistas vulgaris extrai concepções, conceitos e critérios para seu juízo sobre a sociedade do capital e do trabalho assalariado, já se transforma, assim parece, em algo a fisionomia de nossa dramatis personae. (MARX, 1983, p. 145)
\end{abstract}

Ao passar para a esfera oculta da produção onde entra somente "quem fez negócio" (MARX, 1983, p. 144), isto é, só entra quem comprou ou quem vendeu a mercadoria força de trabalho, uma esfera em que não reina a liberdade nem a igualdade entre os indivíduos, estes deixam de representar aqueles possuidores de mercadorias e de dinheiro expostos na seção I, que se dirigiam ao mercado para satisfazer suas necessidades comuns "mediante um ato de vontade comum a ambos" (MARX, 1983, p. 79). Aqui, na passagem para a esfera da produção,

$\mathrm{O}$ antigo possuidor de dinheiro marcha adiante como capitalista, segue-o o possuidor da força de trabalho como seu trabalhador; um, cheio de importância, sorriso satisfeito e ávido por negócios; o outro, tímido, contrafeito, como alguém que levou a sua própria pele para o mercado e agora não tem mais nada a esperar, exceto o - curtume. (MARX, 1983, p. 145)

No momento em que faz a transição da esfera da circulação para a esfera da produção confirma-se a indicação feita por Marx no capítulo II. Os indivíduos se expressam agora como "personificações de relações econômicas” (MARX, 1983, p. 80), uns na condição de capitalistas, outros como proletários. O indivíduo não passa de um personagem que desempenha um papel como integrante de uma classe social que possui interesses antagônicos em relação à outra. As relações sociais deixam de ser idílicas, como haviam se manifestado na seção I, para assumir uma forma dramática, uma forma de luta entre as classes na qual os indivíduos estariam inevitavelmente envolvidos, independentemente, como veremos, de possuírem plena consciência disso.

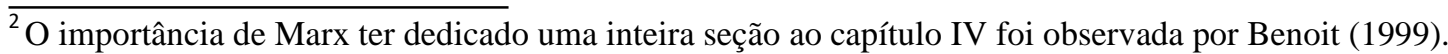

\begin{tabular}{|l|l|l|l|l|}
\hline Revista Dialectus & Ano 1 & n. 1 & Julho-Dezembro 2012 & p. 25-45 \\
\hline
\end{tabular}




\title{
Seção III - "A Produção da Mais-Valia Absoluta" \\ O proletariado como sujeito em contradição com o capital
}

No início do capítulo $\mathrm{V}$, primeiro capítulo da seção III, ao tratar do processo de trabalho comum a todos os modos de produção, Marx afirma que, ao modificar a natureza externa, o homem modifica, ao mesmo tempo, sua própria natureza. $\mathrm{O}$ homem

\begin{abstract}
põe em movimento as forças naturais pertencentes à sua corporalidade, braços e pernas, cabeça e mão, a fim de apropriar-se da matéria natural numa forma útil à sua própria vida. Ao atuar, por meio desse movimento, sobre a Natureza externa a ele e ao modificá-la, ele modifica, ao mesmo tempo, sua própria natureza. (MARX, 1983, p. 149)
\end{abstract}

Fica claro nessa afirmação que, para Marx, não é a consciência que modifica o homem, mas as relações sociais de produção que condicionam uma determinada forma de pensar e agir, portanto, uma consciência social. É nesse sentido que Marx afirma, no Prefácio de Para a crítica da economia política que "não é a consciência dos homens que determina o seu ser, mas, ao contrário, é o seu ser social que determina sua consciência" (MARX, 1986, p. 25). Assim também afirmam Marx e Engels em A ideologia alemã: "A consciência nunca pode ser mais que o ser consciente; e o ser consciente dos homens é o seu processo de vida real". (MARX, 1989, p. 20). Voltaremos a isso mais adiante.

O antagonismo entre as classes, já indicado no final do capítulo IV, se expressa de maneira clara no capítulo VII, terceiro capítulo da seção III, durante uma discussão entre um representante dos trabalhadores e representantes dos capitalistas: "Meus senhores!”, exclama o personagem criado por Marx, que argumenta de forma irônica: “o coração do homem é algo surpreendente, sobretudo quando ele o tem no bolso", ao contrário do que pensais, a perda da última hora da jornada de trabalho "não vos custará o 'lucro líquido' nem às crianças de ambos os sexos, que fazeis trabalhar para vós, a 'pureza da alma'”. (MARX, 1983, p. 183-184) ${ }^{3}$

Se no capítulo VII os interesses dos trabalhadores eram defendidos por um representante fictício, no capítulo seguinte a discussão exposta em $O$ capital torna-se expressão viva da luta real da classe trabalhadora inglesa contra a classe capitalista pela redução da jornada de trabalho. Assim, no capítulo VIII, o personagem criado por Marx é substituído pela própria classe trabalhadora, que ergue sua voz dizendo:

\footnotetext{
${ }^{3}$ Em relação ao significado do caráter dialógico assumido em $O$ capital nesse momento da exposição, ver Benoit (1996).
}

\begin{tabular}{|l|l|l|l|l|}
\hline Revista Dialectus & Ano 1 & n. 1 & Julho-Dezembro 2012 & p. 25-45 \\
\hline
\end{tabular}




\begin{abstract}
Mediante prolongamento desmesurado da jornada de trabalho, podes em 1 dia fazer fluir um quantum de minha força de trabalho que é maior do que o que posso repor em 3 dias. O que tu ganhas em trabalho, eu perco em substância de trabalho. A utilização de minha força de trabalho e a espoliação dela são duas coisas totalmente diferentes. (MARX, 1983, p. 189)
\end{abstract}

Como o próprio Marx observa na nota n 40, essa argumentação foi extraída de uma declaração de um comitê de greve dos trabalhadores da construção civil de Londres em 1860/61. ${ }^{4}$ Nesse capítulo, Marx ingressa até as profundezas dos setores nos quais as condições de trabalho são as mais degradadas: "Lancemos agora o olhar sobre alguns ramos da produção, em que a espoliação da força de trabalho ainda hoje não conhece limites ou até ontem não os conhecia”. (MARX, 1983, p. 196) Ao expor a realidade do interior das fábricas, Marx dá a palavra às crianças trabalhadoras, que denunciam o extremo grau de exploração ao qual são submetidas:

J. Murray, um menino de 12 anos, declara: Eu chego às 6 horas, às vezes às 4 horas da manhã. Trabalhei durante toda a noite passada indo até as 6 horas da manhã. Eu não estive na cama desde a última noite. Além de mim trabalharam 8 ou 9 outros meninos toda a última noite. Todos, com exceção de um, retornaram esta manhã (...) Eu não recebo nada a mais quando trabalho toda a noite. Eu trabalhei, na última semana, durante 2 noites inteiras. (MARX, 1983, p. 197)

Como se vê, nesse momento da exposição é a própria classe trabalhadora quem assume a palavra em $O$ capital. Aqui, depois de terem adquirido experiência como proletários em sua relação com a classe capitalista, o trabalhador não é mais o mesmo em relação àquele que entrou para a esfera da produção, no final do capítulo IV. É nesse sentido que Marx afirma no final do capítulo VIII:

É preciso reconhecer que nosso trabalhador sai do processo de produção diferente do que nele entrou ( ) O contrato pelo qual ele vendeu sua força de trabalho ao capitalista comprovou, por assim dizer, preto no branco, que ele dispõe livremente de si mesmo. Depois de concluído o negócio, descobre-se que ele não era "nenhum agente livre", de que o tempo de que dispõe para vender sua força de trabalho é o tempo em que é forçado a vendê-la, de que, em verdade, seu explorador não o deixa, "enquanto houver ainda um tendão, uma gota de sangue para explorar”. (MARX, 1983, p. 237-238)

O indivíduo proletário vai se transformando por meio da luta de sua classe contra a classe capitalista. A união com seus colegas de classe é um passo inevitável, única forma de se proteger contra o alto grau de exploração de sua força de trabalho. O indivíduo, que na abstrata e ilusória exposição da seção I ia para o mercado atender seus interesses, foi para o mercado na seção II para vender sua força de trabalho para o capitalista, e agora, na seção III, no interior da esfera oculta da produção, este indivíduo, enquanto proletário, não conseguirá atender suas mínimas necessidades a não ser que

\footnotetext{
${ }^{4}$ Ver comentário nesse sentido feito por Benoit (1996).
}

\begin{tabular}{|l|l|l|l|l|}
\hline Revista Dialectus & Ano 1 & n. 1 & Julho-Dezembro 2012 & p. 25-45 \\
\hline
\end{tabular}


"reúna sua cabeça” às de outros trabalhadores (MARX, 1983, p. 238), isto é, a não ser que se organize como membro de uma classe social em luta contra os interesses da classe antagônica.

Como "proteção" contra a serpente de seus martírios, os trabalhadores têm de reunir suas cabeças e como classe conquistar uma lei estatal, uma barreira social intransponível, que os impeça a si mesmos de venderem a si e à sua descendência, por meio de contrato voluntário com o capital, à noite e à escravidão! (MARX, 1983, p. 238)

Como se vê, se no início d 'O capital o indivíduo era submetido e enfeitiçado pelas mercadorias e pelo dinheiro, na seção II este indivíduo não aparece mais na forma indeterminada e abstrata que aparecia na seção I. Ao passar da instância da circulação para a instância da produção, o indivíduo aparece já como proletário, contrariado por estar submetido ao capitalista para quem vendeu sua força de trabalho. Com o posterior desvelamento da mais-valia absoluta no interior da esfera da produção fica claro que na sociedade capitalista o que domina a classe trabalhadora não é apenas a mercadoria e o dinheiro, mas estes passam a representar meras formas de manifestação do capital, esse sujeito automático que busca incessantemente sua autovalorização. (MARX, 1983, p. 130)

A submissão da classe trabalhadora ao capital se dá por meio do próprio processo de produção. É o que Marx demonstra no capítulo IX, último capítulo da seção III. Marx afirma que no capitalismo,

\begin{abstract}
os meios de produção transformaram-se imediatamente em meios para a absorção de trabalho alheio. Não é mais o trabalhador quem emprega os meios de produção, mas os meios de produção que empregam o trabalhador. Em vez de serem consumidos por ele como elementos materiais de sua atividade produtiva, são eles que o consomem como elementos materiais de sua atividade produtiva, são eles que o consomem como fermento de seu próprio processo vital, e o processo vital do capital consiste apenas em seu movimento como valor que valoriza a si mesmo. (MARX, 1983, p. 244)
\end{abstract}

Se o proletariado não passa de uma engrenagem no interior do processo de trabalho e de valorização do valor, algo sem maior autonomia, teria a classe capitalista, afinal, alguma autonomia frente ao capital? Marx vai discutir esta questão no capítulo X, primeiro capítulo da seção IV, que trata da produção da mais-valia relativa. 


\section{Seção IV - "A Produção da Mais-Valia Relativa"}

\section{A burguesia como representante do capital \\ O processo de trabalho como processo educativo}

Na seção IV Marx mostra que, diante do estabelecimento legal de uma jornada de trabalho, a burguesia é forçada a buscar novas formas de apropriação privada de maisvalia. Se a resistência dos trabalhadores impôs limites mais estreitos para o prolongamento da jornada de trabalho, trata-se de procurar aumentar a mais-valia através da redução do valor da força de trabalho, e isto somente é possível por meio da alteração da relação entre o tempo de trabalho necessário para produzir a força de trabalho e o tempo de trabalho excedente, isto é, trata-se de alterar a relação entre o salário e a maisvalia.

Para reduzir o valor da força de trabalho deve ocorrer, como diz Marx, "uma revolução nas condições de produção de seu trabalho", (MARX, 1983, p. 250) a fim de produzir cada mercadoria em menos tempo. No entanto, não é a redução do valor de qualquer mercadoria que influenciará a redução do valor da força de trabalho.

Para que diminua o valor da força de trabalho, o aumento da força produtiva tem de atingir ramos industriais cujos produtos determinam o valor da força de trabalho, que, portanto, ou pertençam à esfera dos meios de subsistência costumeiros ou possam substituí-los. (MARX, 1983, p. 251)

Somente as mercadorias que fazem parte do consumo dos trabalhadores poderão influenciar nas variações do valor da força de trabalho. Mas não são apenas estas mercadorias que influenciam, uma vez que para produzi-las, são necessários meios de produção. Uma variação no valor destes meios de produção utilizados para produzir os meios de subsistência da classe trabalhadora, portanto, também interfere no valor da força de trabalho. (MARX, 1983, p. 251) Curioso é que a ação de reduzir o valor da força de trabalho não é um ato consciente do capitalista individual. É o que Marx afirma a seguir:

Quando um capitalista individual mediante o aumento da força produtiva do trabalho barateia, por exemplo, camisas, não lhe aparece necessariamente como objetivo reduzir o valor da força de trabalho e, com isso, o tempo de trabalho necessário pro tanto, mas na medida em que, por fim, contribui para esse resultado, contribuirá para elevar a taxa geral de mais-valia. (MARX, 1983, p. 251)

Para o capitalista individual proprietário de uma fábrica produtora de camisas, o objetivo de reduzir o valor das camisas é o de vencer a concorrência dos outros capitalistas do mesmo ramo. Para ele trata-se de uma luta inter-capitalista. No entanto,

\begin{tabular}{|l|l|l|l|l|} 
Revista Dialectus & Ano 1 & n. 1 & Julho-Dezembro 2012 & p. 25-45 \\
\hline
\end{tabular}


Marx mostra que esta é apenas a aparência mais superficial, uma vez que o impulso fundamental de reduzir o valor das mercadorias é dado pela luta de classes, isto é, pela luta entre a classe capitalista e a classe proletária. Assim afirma Marx: “(...) as leis imanentes da produção capitalista aparecem no movimento externo dos capitais, (...) se impõem como leis coercitivas da concorrência e assim surgem na consciência do capitalista individual como motivos impulsionadores (...)” (MARX, 1983, p. 252)

Fica claro que nesse momento da exposição o próprio capitalista individual age de maneira relativamente inconsciente, como um mero personagem representante do capital. A luta de classes aparece para ele mistificada na forma aparente da luta concorrencial intercapitalista.

Impulsionados a elevar a produtividade do trabalho para aumentar a produção e a apropriação privada da mais-valia, os capitalistas são estimulados a reunir os trabalhadores para estabelecer a cooperação entre eles. Marx mostra, assim, no capítulo XI, que o próprio processo de produção capitalista, contraditoriamente, reúne e organiza os trabalhadores como classe.

\begin{abstract}
Abstraindo da nova potência de forças que decorre da fusão de muitas forças numa força global, o mero contato social provoca, na maioria dos trabalhos produtivos, emulação e excitação particular dos espíritos vitais (animal spirits) que elevam a capacidade individual de rendimento das pessoas, de forma que 1 dúzia de pessoas juntas, numa jornada simultânea de 144 horas, proporciona um produto global muito maior do que 12 trabalhadores isolados, cada um dos quais trabalha 12 horas, ou do que 1 trabalhador que trabalhe 12 dias consecutivos. (MARX, 1983, p. 260)
\end{abstract}

Doze trabalhadores reunidos pelo capital, cooperando uns com os outros, produzem mais do que 12 trabalhadores trabalhando separadamente. No capitalismo, a reunião dos trabalhadores torna-se inevitável. A seguir, Marx cita um exemplo para esclarecer a questão:

Assim, por exemplo, quando pedreiros formam uma fila de mãos para levar tijolos do pé ao alto do andaime, cada um deles faz o mesmo, mas não obstante as operações individuais formam partes contínuas de uma operação global, fases específicas, que cada tijolo tem de percorrer no processo de trabalho, e pelas quais, digamos, as 24 mãos do trabalhador coletivo o transportam mais rapidamente do que as 2 mãos de cada trabalhador individual que subisse e descesse o andaime. $\mathrm{O}$ objeto de trabalho percorre o mesmo espaço em menos tempo. (MARX, 1983, p. 260)

O trabalhador individual é apenas um elemento constituinte de algo superior a ele, sua classe social, reunida e organizada inevitavelmente pelo próprio capital. Com o decorrer da exposição d'O capital, tanto o capitalista individual quanto o trabalhador individual vão tornando-se meros representantes de suas próprias classes. As relações sociais, que apareciam no capítulo I como relações entre as mercadorias e o dinheiro, no

\begin{tabular}{|l|l|l|l|l|}
\hline Revista Dialectus & Ano 1 & n. 1 & Julho-Dezembro 2012 & p. 25-45 \\
\hline
\end{tabular}


capítulo II como relações entre indivíduos produtores de mercadorias, no capítulo IV como capitalista e trabalhador individual, passam a ser descritas agora como relações entre classes sociais.

Ao mesmo tempo em que o trabalhador, no interior do processo de trabalho, é um elemento constituinte de sua própria classe, ele passa a ser, segundo Marx, de forma contraditória, um elemento constituinte do próprio capital. "Como cooperadores, como membros de um organismo que trabalha, eles não são mais do que um modo específico de existência do capital." (MARX, 1983, p. 264) Ao produzir cotidianamente o alimento do capital, o mais-trabalho que se expressa em mais-valia, a classe trabalhadora reproduz, contraditoriamente, o seu algoz, o capital.

Assim como nos capítulos VII e VIII, as relações entre as classes continuam a se manifestar como relações antagônicas, como luta de classes. "Com a massa de trabalhadores ocupados ao mesmo tempo cresce também sua resistência e com isso necessariamente a pressão do capital para superar essa resistência”. (MARX, 1983, p. 263)

Como se vê, a reunião e a organização dos trabalhadores enquanto classe é proporcionada e garantida, contraditoriamente, pelo próprio capital. É nesse sentido que Marx afirma a seguir: “( ) a cooperação dos assalariados é mero efeito do capital, que os utiliza simultaneamente. A conexão de suas funções e sua unidade como corpo total produtivo situa-se fora deles, no capital, que os reúne e os mantém unidos" (MARX, 1983, p. 263). Na época dos monopólios, esta reunião e organização ganha dimensões planetárias. O grande capital não organiza os trabalhadores apenas localmente, mas mundialmente. A união internacional dos trabalhadores, levantada como bandeira por Marx e Engels no final do Manifesto Comunista ${ }^{5}$ é, até certo ponto, de maneira contraditória, produzida e impulsionada pelo próprio capital.

O capital organiza e explora os trabalhadores mediante um plano que lhes é imposto contra a sua vontade. “A conexão de seus trabalhos se confronta idealmente, portanto, como plano, na prática como autoridade do capitalista, como poder de uma vontade alheia, que subordina sua atividade ao objetivo dela". (MARX, 1983, p. 263) A imposição deste plano é realizada pelo representante do capital de forma despótica, ou seja, o que reina no interior dos locais de trabalho é a ditadura do capital.

\footnotetext{
${ }^{5}$ No final do Manifesto Comunista Marx e Engels conclamam os trabalhadores de todo o mundo a se unirem: "Proletários de todos os países: uni-vos!" (Marx \& Engels, Manifesto Comunista. São Paulo: Boitempo, 1998, p. 69.
}

\begin{tabular}{|l|l|l|l|l|} 
Revista Dialectus & Ano 1 & n. 1 & Julho-Dezembro 2012 & p. 25-45 \\
\hline
\end{tabular}


Se, portanto, a direção capitalista é, pelo seu conteúdo, dúplice, em virtude da duplicidade do próprio processo de produção que dirige, o qual por um lado é processo social de trabalho para a elaboração de um produto, por outro, processo de valorização do capital, ela é quanto à forma despótica. (MARX, 1983, p. 263)

Vejamos novamente, de forma sintética, o que Marx expôs nesse capítulo. A mera reunião dos trabalhadores realizada pelo próprio processo de produção capitalista tende a aumentar sua resistência contra o plano de trabalho que lhes é imposto de forma autoritária e que se opõem a sua própria vontade. Considerando o que Marx afirmou no início do capítulo $\mathrm{V}$, que "ao modificar a natureza externa o homem modifica, ao mesmo tempo, sua própria natureza" (MARX, 1983, p. 149), poderíamos perguntar, então, se este processo contraditório da luta de classes no interior do processo de trabalho não poderia servir como um processo educativo para a classe trabalhadora, um processo no qual, ao educar-se os trabalhadores, ao mesmo tempo, se modificando? Ao educarem-se e modificarem-se, não estariam os trabalhadores se tornando aptos a elaborarem um plano oposto ao plano do capitalista? Não seria, em certo sentido, o próprio processo da luta de classes um processo educativo da classe trabalhadora?

No entanto, este processo educativo não pode ser confundido com um processo educativo formal, escolar e pedagógico, pois representa um processo no qual os trabalhadores podem passar a compreender as relações contraditórias de classe através de sua própria experiência, através de sua própria luta em defesa de seus interesses, que processo que pode, aos poucos, ir desvelando para eles os limites da classe capitalista em atender suas necessidades mais elementares.

Nesse momento da exposição, esse processo educativo está, no entanto, muito aquém do momento no qual revelará os fundamentos sob os quais se ocultam os fenômenos. Aqui o capital aparece ainda na forma mistificada de um sujeito automático, noção exposta já no capítulo IV e que ainda permanece. Nesse sentido, afirma Marx:

\footnotetext{
A força produtiva social do trabalho desenvolve-se gratuitamente tão logo os trabalhadores são colocados sob determinadas condições, e o capital os coloca sob essas condições. Uma vez que a força produtiva social do trabalho não custa nada ao capital e, por outro lado, não é desenvolvida pelo trabalhador, antes que seu próprio trabalho pertença ao capital, ela aparece como força produtiva que o capital possui por natureza, como sua força produtiva imanente. (MARX, 1983, p. 264)
}

Aos trabalhadores, que são os únicos que produzem novo valor e mais-valor, parece que tudo provém do capital, isto é, parece que toda a riqueza e toda potencialidade produtiva provém ou do valor antigo materializado nos meios de produção, ou do dinheiro que compra esses meios de produção e compra sua própria

\begin{tabular}{|l|l|l|l|l|} 
Revista Dialectus & Ano 1 & n. 1 & Julho-Dezembro 2012 & p. 25-45 \\
\hline
\end{tabular}


força de trabalho, ou mesmo das mercadorias produzidas por eles próprios no processo de trabalho, ou ainda do dinheiro obtido pela venda destas mercadorias. Não lhes ocorre que toda a riqueza provém do seu trabalho excedente não pago pelos capitalistas.

Como se vê, quando as mercadorias e o dinheiro se transformam em formas de manifestação do capital, o feitiço que elas exercem sobre os homens supera a instância da circulação e se expande para a instância da produção. Não são apenas as relações de troca entre os homens que aparece agora como relações entre coisas, como foi observado no capítulo I. Aqui a própria produção da riqueza aparece para os produtores como uma ação de um sujeito transcendental, invisível, onipotente e onipresente, o capital.

Os homens, tanto trabalhadores quanto capitalistas, são dominados pelo movimento do capital. Quando, no capítulo XII, Marx trata da divisão do trabalho e da manufatura, a subordinação do trabalhador coletivo ao capital fica ainda mais determinada.

\footnotetext{
Por um lado a manufatura introduz (...) a divisão do trabalho em um processo de produção ou a desenvolve mais; por outro, ela combina ofícios anteriormente separados. Qualquer que seja seu ponto particular de partida, sua figura final é a mesma - um mecanismo de produção, cujos órgãos são seres humanos. (MARX, 1983, p. 268)
}

O trabalhador individual cumpre um mero papel de engrenagem que repete mecanicamente o mesmo movimento no interior de um processo de trabalho. $\mathrm{O}$ trabalhador individual é transformado pelo processo de produção capitalista num verdadeiro autômato: “descendo agora aos pormenores, é desde logo claro que um trabalhador, o qual executa a sua vida inteira uma única operação simples, transforma todo o seu corpo em órgão automático unilateral dessa operação (...)”. (MARX, 1983, p. 269)

No trecho a seguir, mais uma vez Marx mostra como o trabalhador individual não passa de uma abstração, um componente do trabalhador coletivo. "Com uma parte de suas mãos armadas de instrumentos, o trabalhador coletivo, formado pela combinação de trabalhadores detalhistas, estira o arame, enquanto simultaneamente com outras mãos e outras ferramentas o estica, com outras o corta, o aponta, etc." (MARX, 1983, p. 272273)

O desenvolvimento do trabalhador coletivo, enquanto força produtiva do capital, vai ganhando independência do desenvolvimento do trabalhador individual, podendo até mesmo se tornar antagônico a este desenvolvimento.

\begin{tabular}{|l|l|l|l|l|}
\hline Revista Dialectus & Ano 1 & n. 1 & Julho-Dezembro 2012 & p. 25-45 \\
\hline
\end{tabular}




\begin{abstract}
Os conhecimentos, a compreensão e a vontade, que o camponês ou artesão autônomo desenvolve mesmo que em pequena escala, como o selvagem exercita toda arte da guerra como astúcia pessoal, agora passam a ser exigidos apenas pela oficina em seu conjunto. As potências intelectuais da produção ampliam sua escala por um lado, porque desaparecem por muitos lados. O que os trabalhadores parciais perdem, concentra-se no capital com que se confrontam. (MARX, 1983, p. 283)
\end{abstract}

O desenvolvimento do processo capitalista de produção, que domina o trabalhador coletivo transformando-o em sua força própria, "mutila o trabalhador, convertendo-o em trabalhador parcial (...) $\mathrm{Na}$ manufatura, o enriquecimento do trabalhador coletivo e, portanto, do capital em força produtiva social é condicionado pelo empobrecimento do trabalhador em forças produtivas individuais”. (MARX, 1983,

p. 283-284), a ponto de impulsionar uma verdadeira patologia industrial. (MARX, 1983, p. 285) Quão atual é esta afirmação de Marx podem provar as inúmeras novas doenças do trabalho, sobretudo aquelas surgidas após a inclusão da informática nos processos de trabalho. Uma das mais comuns é a LER (lesão por esforço repetitivo), que em poucos anos transforma o trabalhador em uma pessoa prematura e definitivamente inapta ao trabalho.

A luta de classes aparece em $O$ capital como resultado do aumento do grau de exploração do trabalhador que leva à sua mutilação. Apesar de buscar incessantemente sufocar a iniciativa da classe trabalhadora, a classe capitalista não é capaz de realizar totalmente este feito: "Uma vez que a habilidade artesanal continua a ser a base da manufatura e que o mecanismo global que nela funciona não possui nenhum esqueleto objetivo independente dos próprios trabalhadores, o capital luta constantemente com a insubordinação dos trabalhadores”. (MARX, 1983, p. 288)

O papel do capitalista enquanto mero representante do capital e este aparecendo como sujeito automático, como já havia sido descrito no capítulo IV, é exposto novamente no capítulo XIII, que trata da maquinaria e da grande indústria. "Enquanto capital - e enquanto tal o autômato tem no capitalista consciência e vontade - está animada pelo impulso de reduzir a opositiva mas elástica limitação natural do ser humano à resistência mínima”. (MARX, 1983, tomo 2, p. 29) Materializado na maquinaria, o capital choca-se com "as limitações naturais de seus auxiliares humanos: sua fraqueza corporal e sua vontade própria”. (MARX, 1983, p. 29) Aparece novamente aqui a luta entre a ânsia ilimitada do capital por mais-valia e os limites orgânicos dos trabalhadores. 


\title{
Seção VI - "O Salário"
}

\section{A alienação dos trabalhadores produzida pelo próprio processo de produção}

No capítulo XVII, primeiro capítulo da Seção VI, no qual Marx trata a respeito da transformação do valor da força de trabalho em salário, fica claro como o feitiço do dinheiro, quando assume a forma de salário, impede que os trabalhadores percebam que estão fornecendo gratuitamente trabalho excedente à classe capitalista. Assim, diz Marx: “A forma salário extingue (...) todo vestígio da divisão da jornada de trabalho em trabalho necessário e mais-trabalho, em trabalho pago e trabalho não pago. Todo trabalho aparece como trabalho pago". (MARX, 1983, tomo 2, p. 130) Segundo Marx, isso é o que distingue a forma que o trabalho excedente assume na sociedade capitalista em comparação com as sociedades pré-capitalistas.

\begin{abstract}
Na corvéia distinguem-se espacial e temporalmente, de modo perceptível para os sentidos, o trabalho do servo para si mesmo e seu trabalho forçado para o senhor da terra. No trabalho escravo, a parte da jornada de trabalho em que o escravo apenas repõe o valor de seus próprios meios de subsistência, em que, portanto, realmente só trabalha para si mesmo, aparece como trabalho não pago. (MARX, 1983, tomo 2, p. 130)
\end{abstract}

No capitalismo há um velamento do trabalho não pago, ficando este oculto para o trabalhador. "No trabalho assalariado, ao contrário, mesmo o mais-trabalho ou trabalho não pago aparece como trabalho pago. Ali a relação de propriedade oculta o trabalho do escravo para si mesmo; aqui a relação de dinheiro oculta o trabalho gratuito do assalariado". (MARX, 1983, tomo 2, p. 130)

Por meio da forma salário, o capitalismo tornou-se o modo mais sofisticado de apropriação privada de trabalho excedente. Enquanto nos modos de produção anteriores o velamento do trabalho não pago era frágil, exigindo uma enorme super-estrutura ideológica para apaziguar as classes trabalhadoras, no capitalismo a alienação da consciência do proletariado é, até certo ponto, produzida pelas próprias relações de produção. Nesse sentido diz Marx:

(sobre o salário) que torna invisível a verdadeira relação e mostra justamente o contrário dela, repousam todas as concepções jurídicas tanto do trabalhador como do capitalista, todas as mistificações do modo de produção capitalista, todas as suas ilusões de liberdade, todas as pequenas mentiras apologéticas da Economia vulgar. (MARX, 1983, tomo 2, p. 130)

No processo de luta de classes, a classe trabalhadora poderá superar o feitiço gerado pela sua própria mercadoria, a força de trabalho, isto é, poderá superar o feitiço 
em torno do seu valor de troca - o salário - e do seu valor de uso, a capacidade de criar mais valor do que ela própria vale.

No capítulo XIX, ao tratar sobre o salário por peça, Marx mostra que é justamente no momento em que o trabalhador tem a impressão de que conquistará maior liberdade o momento no qual o capital mais o domina, jogando-o numa acirrada concorrência com seus colegas de classe. "A maior liberdade que o salário por peça oferece à individualidade tende a desenvolver, por um lado, a individualidade, e com ela o sentimento de liberdade, a independência e autocontrole dos trabalhadores; por outro, a concorrência entre eles e de uns contra os outros". (MARX, 1983, tomo 2, p. 142)

\title{
Seção VII - "O Processo de Acumulação do Capital" \\ O desvelamento final e constituição do proletariado em sujeito revolucionário
}

No capítulo XXI, primeiro capítulo da Seção VII, última seção do Livro I, o papel assumido pelo capital de sujeito de sua própria valorização serve para desvelar um dos segredos da propriedade privada capitalista. Nesse sentido, Marx afirma que

\begin{abstract}
Se a mais-valia produzida periodicamente, por exemplo, anualmente, por um capital de 1.000 libras esterlinas, for de 200 libras esterlinas e se essa maisvalia for consumida todos os anos, é claro que, depois de repetir-se o mesmo processo durante 5 anos, a soma da mais-valia consumida será $=5$ x 200, ou igual ao valor do capital originalmente adiantado de 1.000 libras esterlinas. Se a mesma mais-valia fosse apenas parcialmente consumida, por exemplo só pela metade, teríamos o mesmo resultado, após 10 anos de repetição do processo de produção, pois 10 x $100=1.000$. (MARX, 1983, tomo 2, p. 155)
\end{abstract}

Este raciocínio de Marx comprova que a nova propriedade privada representada nas 1.000 libras esterlinas não é nada mais do que mais-valia capitalizada (5 anos x 200 libras esterlinas por ano de mais-valia), isto é, a nova propriedade não passa de trabalho alheio não pago à classe trabalhadora. Por meio do movimento de vários ciclos de produção Marx demonstra que no decorrer de vários anos a própria propriedade privada capitalista provém do desgaste de cérebro, músculos e nervos da classe trabalhadora. Fica clara aqui a razão que levou Marx a chamar, no capítulo IV, o capital de sujeito automático que usurpa tempo de trabalho alheio. (MARX, 1983, p. 130)

Portanto, na última seção do Livro I realiza-se um processo desvelamento da propriedade privada capitalista. Esta é fruto do roubo. O próprio salário, que aparentemente era pago pelo capitalista, também provém da mais-valia apropriada anteriormente. $\mathrm{Na}$ verdade, durante a jornada de trabalho, a própria classe trabalhadora produz o seu salário atual e o seu salário futuro. A classe capitalista apenas repassa o

\begin{tabular}{|l|l|l|l|l|}
\hline Revista Dialectus & Ano 1 & n. 1 & Julho-Dezembro 2012 & p. 25-45 \\
\hline
\end{tabular}


valor do salário dos trabalhadores utilizando a mais-valia apropriada anteriormente. Não há troca de equivalentes na relação de compra e venda da força de trabalho entre a classe capitalista e a classe trabalhadora. É o que Marx afirma nesta passagem do capítulo XXII:

\begin{abstract}
O intercâmbio de equivalentes, que apareceu como a operação original, se torceu de tal modo que se troca apenas na aparência, pois, primeiro, a parte do capital que se troca por força de trabalho nada mais é que uma parte do produto de trabalho alheio, apropriado sem equivalente, e segundo, ela não somente é reposta por seu produtor, o trabalhador, como este tem de repô-la com novo excedente. A relação de intercâmbio entre capitalista e trabalhador torna-se, portanto, apenas mera aparência pertencente ao processo de circulação, mera forma, que é alheia ao próprio conteúdo e apenas o mistifica. (MARX, 1983, tomo 2, p. 166)
\end{abstract}

Marx mostra assim que a relação entre a classe capitalista e a classe trabalhadora não passa de uma farsa.

No capítulo XXIII o desemprego é considerado como algo imanente, necessário e indispensável ao modo de produção capitalista.

\begin{abstract}
A lei que mantém a superpopulação relativa ou exército industrial de reserva sempre em equilíbrio com o volume e a energia da acumulação prende o trabalhador mais firmemente ao capital do que as correntes de Hefaísto agrilhoaram Prometeu ao rochedo. Ela ocasiona uma acumulação de miséria correspondente à acumulação de capital. (MARX, 1983, tomo 2, p. 210)
\end{abstract}

Marx defende, então, a solidariedade entre os trabalhadores empregados e os desempregados, indicando que é fundamental buscar a necessária união entre os diversos extratos da classe trabalhadora. (MARX, 1983, tomo 2, p. 206)

Se a relação entre capital e trabalho é uma farsa, farsa também é a ideia de que o capital se originou do trabalho da classe capitalista. No capítulo XXIV Marx cita diversos exemplos históricos para provar que o capital não apenas foi originado, mas se reproduz permanentemente por meio da violenta separação dos trabalhadores e os meios de produção. "Tão logo a produção capitalista se apóie sobre seus próprios pés, não apenas conserva aquela separação, mas a reproduz em escala sempre crescente”. (MARX, 1983, tomo 2, p. 262)

No final do capítulo XXIV Marx mostra que a superação do feudalismo foi historicamente necessária para liberar o desenvolvimento das forças produtivas que aquele modo de produção havia passado a bloquear a partir do século XV. Da mesma forma, depois de alguns séculos, em meados do século XIX, o capitalismo tornou-se o bloqueio àquele desenvolvimento e, pela mesma razão, deveria ser superado. A tendência histórica traçada por Marx no final deste capítulo foi, pois, a negação da negação, isto é, a negação da propriedade privada capitalista que nega o livre

\begin{tabular}{|l|l|l|l|l|} 
Revista Dialectus & Ano 1 & n. 1 & Julho-Dezembro 2012 & p. 25-45 \\
\hline
\end{tabular}


desenvolvimento das forças produtivas. A violência originária seria realizada, então, sob nova forma, a expropriação dos expropriadores, embora exija um grau infinitamente inferior àquele utilizado para fazer nascer o capitalismo. ${ }^{6}$ Afirma Marx:

A transformação da propriedade privada parcelada, baseada no trabalho próprio dos indivíduos, em propriedade capitalista é, naturalmente, um processo incomparavelmente mais longo, duro e difícil do que a transformação da propriedade capitalista, realmente já fundada numa organização social da produção, em propriedade social. Lá, tratou-se da expropriação da massa do povo por poucos usurpadores, aqui trata-se da expropriação de poucos usurpadores pela massa do povo. (MARX, 1983, tomo 2, p. 294)

Quem seria o sujeito capaz de realizar esta tarefa histórica? Marx cita uma passagem do Manifesto Comunista:

O progresso da indústria, cujo portador involuntário e não-resistente é a burguesia, coloca no lugar do isolamento dos trabalhadores, pela concorrência, sua união revolucionária, pela associação. Com o desenvolvimento da grande indústria, a burguesia vê, pois, desaparecer sob seus pés o fundamento sobre o qual ela produz e se apropria dos produtos. Ela produz, pois, antes de mais nada, seus próprios coveiros. Sua queda e a vitória do proletariado são igualmente inevitáveis. (...) De todas as classes que hoje se defrontam com a burguesia, apenas o proletariado é uma classe realmente revolucionária. As demais classes degeneram e desaparecem com a grande indústria, o proletariado é seu produto mais genuíno. Os estamentos médios, o pequeno industrial, o pequeno comerciante, o artesão, o camponês, todos eles combatem a burguesia para evitar que sua existência como estamentos médios se extinga (...) eles são reacionários, pois procuram girar a roda da história para trás. (Citado em MARX, 1983, tomo 2, p. 294)

No final do Livro I, a classe trabalhadora, "sempre numerosa, educada, unida e organizada pelo próprio mecanismo do processo de produção capitalista" (MARX, 1983, tomo 2, p. 294), depois de lutar pela redução da jornada de trabalho, depois de desvelar os segredos ocultos por trás da forma salário, depois de desvelar a origem da propriedade privada capitalista, depois de percorrer este longo e árduo percurso da luta de classes, torna-se, finalmente, um sujeito revolucionário capaz de realizar de forma consciente a violência revolucionária, agora sob nova forma.

Marx faz, portanto, neste Livro I, uma totalização, por partir do feitiço absoluto, das mercadorias circulando sozinhas no mercado, até chegar ao proletariado como sujeito revolucionário. O resultado até aqui obtido já pode ser considerado, portanto, uma totalização, ainda que uma totalização abstrata, pois no Livro I ainda esta abstraída a concorrência entre os capitais, exposta no Livro II, e a reprodução do capital social total, exposto no Livro III.

\footnotetext{
${ }^{6}$ Marx faz uma analogia do surgimento de um novo modo de produção com o nascimento de uma nova pessoa: "A violência é a parteira de toda velha sociedade que está prenhe de uma nova. Ela mesma é uma potência econômica”. (MARX, 1983, tomo 2, p. 286)
}

\begin{tabular}{|l|l|l|l|l|} 
Revista Dialectus & Ano 1 & n. 1 & Julho-Dezembro 2012 & p. 25-45 \\
\hline
\end{tabular}




\section{Livros II e III - "O Processo de Circulação do Capital” e "O Processo Global da produção Capitalista"}

No Livro II Marx vai voltar a tratar do capital como sujeito. Na seção I vai expor as três formas de manifestação de capital, dependendo do ponto a partir do qual se inicia a análise, resultando assim no ciclo do capital-monetário, no ciclo do capital-produtivo e o ciclo do capital-mercadoria. Na seção III Marx vai mostrar como os diferentes capitais se relacionam de acordo com o Departamento ao qual pertencem, o Departamento I, produtor de meios de produção, e o Departamento II, produtor de meios de subsistência. Como se vê, o indivíduo volta a ser tratado como uma abstração também no Livro II. A análise da concorrência é realizada tomando-se em conta a relação entre capitais.

No Livro III, Marx mostra que as crises do capital ocorrem não porque há o aumento da quantidade de pessoas passando fome, não porque há um crescente nível de miséria e de desemprego, mas porque há reduzida valorização do capital. As crises não ocorrem porque há escassez de mercadorias no mercado em relação à demanda, mas pelo contrário, o capital entra em crise em decorrência do excesso relativo de mercadorias, ou seja, do excesso de mercadorias em relação àqueles que têm capacidade de comprálas. O capitalismo entra em crise quando há abundância, não quando há escassez. O objetivo do capital não é atender as necessidades humanas. O atendimento dessas necessidades é apenas um meio de atender as necessidades do capital, que é valorizar o valor. Mais uma vez o capital é descrito como um sujeito automático que domina os indivíduos. Frente ao capital e suas crises imanentes o indivíduo torna-se totalmente incapaz de qualquer ação. Mais uma vez, os indivíduos são desprezados e submetidos totalmente ao processo de valorização do valor.

Na última seção do Livro III, a seção VII, Marx inclui mais uma classe, além das duas expostas nos Livros I e II, a classe capitalista e da classe trabalhadora. Trata-se da classe dos proprietários fundiários, que vivem da renda da terra. Marx encerra o Livro III no capítulo LII, que trata sobre as classes. As classes sociais, em suas relações antagônicas, finalizariam, assim, o projeto dos três livros d'O capital, este longo percurso que transformou o indivíduo enfeitiçado num membro de uma classe social em luta contra a classe antagônica.

\begin{tabular}{|l|l|l|l|l|} 
Revista Dialectus & Ano 1 & n. 1 & Julho-Dezembro 2012 & p. 25-45 \\
\hline
\end{tabular}




\section{Considerações finais}

Segundo Marx, enquanto existirem classes sociais, os indivíduos continuarão sendo uma abstração, "personificações de relações econômicas” (MARX, 1983, p. 80). Somente numa sociedade sem classes os indivíduos poderão desenvolver livremente toda a sua potencialidade criativa e produtiva. Somente quando os indivíduos se libertarem da ditadura dos locais de trabalho, da ditadura do mercado que lhes impõem uma divisão do trabalho forçada para toda a vida, como afirmaram Marx e Engels em A ideologia alemã, "ser caçador, pescador, pastor ou crítico", divisão do trabalho da qual eles não podem fugir se não quiserem perder seus meios de subsistência, somente quando eles tiverem a possibilidade "de hoje fazer uma coisa, amanhã outra, caçar de manhã, pescar na parte da tarde, cuidar do gado ao anoitecer, fazer crítica após as refeições, ao bel prazer, sem nunca tornar-se caçador, pescador ou crítico (MARX; ENGELS, 1989, p. 29) somente então poderemos falar de verdadeiros e plenos indivíduos.

\section{Referências bibliográficas}

BENOIT, H. Sobre a crítica (dialética) de $\boldsymbol{O}$ capital. In: Revista Crítica Marxista, $\mathrm{n}^{\circ}$ 3, São Paulo: Brasiliense, 1996.

\section{Pensando com (ou contra) Marx? Sobre o método dialético de $O$}

capital. In: Crítica marxista, no 8, São Paulo: Xamã, junho/1999.

MARX, Karl. O capital. Crítica da economia política. São Paulo: Nova Cultural, 1983.

Nova Cultural, 1986.

Para a crítica da economia política (Prefácio). In: Marx. São Paulo:

.; ENGELS, F. A ideologia alemã. São Paulo: Martins Fontes, 1989.

Manifesto comunista. São Paulo: Boitempo, 1998.

\begin{tabular}{|l|l|l|l|l|} 
Revista Dialectus & Ano 1 & n. 1 & Julho-Dezembro 2012 & p. 25-45 \\
\hline
\end{tabular}

